\title{
BASTA! Reflexóes em torno da Covid-19
}

\section{| ${ }^{1}$ Maria Andrea Loyola |}

\author{
${ }^{1}$ Instituto de Medicina Social, Universidade do Estado do Rio de Janeiro. Rio de Janeiro-RJ, Brasil (andrea.loyola@terra.com.br). \\ ORCID: 0000-0003-1442-9628 \\ Recebido em: 21/04/2020 \\ Aprovado em: 25/04/2020 \\ Revisado em: 28/04/2020
}

DOI: http://dx.doi.org/10.1590/S0103-73312020300213

Esse vírus que nos ataca impiedosamente parece que chegou para dizer "basta!". Basta de cegueira e hipocrisia; de fazer de conta que a pobreza, a precariedade e o abandono de uma parte significativa da população só existem nas estatísticas portanto, bem camufladas e invisíveis.

Basta de continuarmos investindo nesse sistema que só produz desigualdade e uma vergonhosa concentração de renda que não somos sequer capazes de imaginar, a náo ser pelos pequenos números que a descrevem. Basta de defendermos ajustes fiscais que só ajustam para cima os lucros dos bancos e dos empresários e que garantem o padrão de consumo das classes dominantes (ambas palavras fora de moda).

Basta de acreditarmos na eficiência do setor privado e da inépcia do setor público, e principalmente que eles se opóem. Sob essa visão reducionista classificada como neoliberal, esses contrastes vão se acentuando e mergulhando na miséria o trabalhador desempregado. E nós, que somos obrigados a pensar sobre isso, também aceitamos nos submeter e incorporar na academia o pensamento que justifica e mantém essa situação. Veja o quantativismo/produtivista que orienta nossas produçôes acadêmicas e nossos projetos voltados mais para o prestígio do que para a dramática realidade de saúde do país. 
Mas a Covid-19 trouxe também à luz a importância dos sanitaristas, que ainda no século passado construíram o SUS e, através da Constituição de 1988, tornaram a saúde um direito universal e um dever do Estado. Princípios estes gradativamente desconsiderados pelos últimos governos e pelo abandono do SUS em prol de uma medicina suplementar, de alto nível, para os ricos, e de baixo nível, para os pobres. De abandono igualmente de investimentos em uma produçáo local de medicamentos pela indústria nacional que só favorece os grandes laboratórios - donde a tão criticada “judicialização" da saúde, que também não serve aos mais pobres, que continuam dependentes dos medicamentos essenciais.

Foram também os sanitaristas os responsáveis pela criação, entre muitos outros, do Programa de Saúde da Família e da modelagem do Programa Brasileiro de Combate à Aids, internacionalmente aplaudido e copiado.

A Covid-19 deixou bem claro que o SUS era a única salvação de um país que, por puro preconceito, não valoriza a saúde pública e prefere investir em estádios esportivos milionários do que em modestos, mas bem equipados e eficientes hospitais. Não por acaso, um ministro da Saúde, que antes era visto de terno e identificado com a medicina privada, passou a dar entrevistas vestindo o colete do SUS e defendendo a Saúde Pública.

Claro que se trata aqui de uma análise sucinta de uma realidade plena de nuances e contradiçôes que não cabem ser discutidas aqui. $\mathrm{O}$ que me interessa, principalmente, é responder à questão que dirijo também aos meus colegas do IMS:

o que permitiu aos sanitaristas do passado recente fazerem o que fizeram pela saúde no Brasil?

Não estou me referindo aos sanitaristas em geral, nem apenas aos médicos. Refirome a todos aqueles que, de alguma forma, participaram do movimento sanitarista, que também não cabe ser detalhado aqui: médicos, enfermeiros, sociólogos, cientistas políticos, assistentes sociais, filósofos, psicanalistas, antropólogos e demais profissionais pertencentes à Saúde Coletiva. Se existia um contexto favorável, inclusive já bastante discutido, é sobretudo à atividade acadêmica que minha questão se dirige. E nesse sentido, minha hipótese é que esses profissionais se orientavam e parte deles ainda se orienta pelo paradigma marxista.

É fartamente conhecido que o mundo e o país mudaram e que o contexto atual é muito diferente daquele de meados do não longínquo século XX. O trabalho e as relaçôes de trabalho mudaram, o contrato social baseado no trabalho, erigido após a 
Segunda Guerra Mundial e que permitiu a criação do Estado do Bem-Estar Social - do qual a educação, a saúde e a previdência eram os pilares- esfacelou-se. Em seu lugar vieram a precariedade, o descompromisso com os pobres, o individualismo no lugar do coletivismo (ainda presente no termo "Saúde Coletiva").

O paradigma dos direitos humanos tornou-se hegemônico na defesa da justiça social e da democracia, e sob esse aspecto, é realmente funda mental - mas a concepção de direitos humanos baseada apenas no direito das minorias, classificadas sobretudo por critérios tidos como biológicos: negros, mulheres, homossexuais, portadores de deficiências físicas, todos historicamente vítimas de preconceitos. Minorias ajudam a transformar o mundo, mas por sua própria condição são incapazes de liderar um movimento social com possibilidades reais de alterar as estratégias de conservação das atuais estruturas de poder. E o que interessa para essa proposta, nos dificulta, ou mesmo impede de pensar o coletivo, no sentido amplo do termo. Assim, o paradigma dos direitos humanos, que no dizer de Samuel Moyn (RIOS, 2013), constitui nossa última ilusão para pensar a própria democracia, prescinde, a meu ver, de conceitos que focalizem as desigualdades sociais, como ocorreu na origem do movimento sanitarista de diferentes países latino-americanos e europeus.

É claro que, tendo em vista as mudanças apontadas acima, os conceitos, tal como formulados por aqueles pensadores, não nos servem mais para uma análise crítica da sociedade e principalmente da saúde pública. Mas a realidade que eles procuravam analisar deixou de existir?

Com a queda do muro de Berlim, o conceito de classes sociais foi abolido completamente da vida acadêmica, assim como outros conceitos da teoria marxista, como aquele que pontifica que não é o capital, mas o trabalho que cria valor e que a acumulação capitalista é feita através da extração da mais valia do trabalho, notadamente do trabalho assalariado.

O abandono do conceito de classes aboliu a realidade das classes? A extração da mais valia deixou de existir? Apenas mudaram de forma: as classes sociais são agora definidas principalmente pelo nível de renda e de consumo (categorias de marketing ligadas ao mercado); e a mais valia extraída pelo próprio indivíduo, condenado a trabalhar exaustivamente para aumentar sua produtividade. E, com a informatização, muda o ambiente de trabalho, mas não a apropriação pelos detentores do capital do excedente do trabalho humano. 
Não estou convocando aqui para o retorno à teoria marxista. Estou convocando para a valorização daqueles conceitos da Saúde Coletiva que já nos servem e para a construção de novos conceitos baseados numa visão de tipo marxista; ou seja, conceitos que nos permitam pensar a saúde de um ponto de vista das desigualdades sociais e de atuar no sentido de diminuí-las. Não necessariamente através de açôes diretas, mas sobretudo através de nossa função maior: ensinar e produzir conhecimentos. E conhecimentos que sirvam de base à formulação de políticas públicas e ajudem os gestores, os juristas, à mídia, os políticos que atuam na área parlamentar, não somente a formulá-las, mas que os ajudem, sobretudo, a enxergarem em funçáo de quem e para quem eles estáo agindo. Os conceitos, como não se cansa de repetir Pierre Bourdieu, servem para elucidar, mas também para encobrir a realidade sobre a qual pretendemos atuar (LOYOLA, 2002).

Em suma, estou conclamando, aqui, a voltarmos a pensar de forma crítica; para isso, precisamos de ferramentas conceituais, para não precisarmos que um vírus, com o qual lidamos frequentemente, venha nos mostrar o que devemos priorizar em nossa atividade e produçáo acadêmica.

\section{Referências}

LOYOLA, M.A. Bourdieu e a Sociologia. In: Pierre Bourdieu. Rio de Janeiro: EdUERJ, 2002 (Coleção Pensamento Contemporâneo).

RIOS, A. Samuel Moyn. Entrevistado por André Rios. Rio de Janeiro: EdUERJ/Faperj, 2013 (Coleção Pensamento Contemporâneo). 